\title{
The second eradication: Rinderpest
}

\section{La deuxième éradication : la peste bovine}

\section{F. Moutou}

Received: 30 November 2013; Accepted: 22 January 2014

(C) Société de pathologie exotique et Springer-Verlag France 2014 ease, Peter Doherty, Nobel Prize for medicine in 1996, recalled the importance of such an event, much farther than just an animal health topic. It is, indeed, a disease of domestic cattle, but its history is far from being negligible for humankind [6].

Rinderpest is everything but unknown. It is caused by a virus belonging to the Paramyxoviridae family and from the genus Morbillivirus, very close from the virus responsible of human measles. Today, virologists admit that measles virus is the adaptation to human beings of the rinderpest virus through cattle domestication process. As the wild ox (Bos primigenius), ancestor of all domestic livestock, with or without hump, was brought to extinction during the XVII ${ }^{\text {th }}$ century, it may not be reachable to confirm this hypothesis. It is also possible to notice that no other Morbillivirus is known in wild primates, even if apes in captivity are susceptible to the virus and to the disease. From an evolutionary and adaptive point of view, it should be mentioned that cattle rinderpest virus, as the human measles virus, is surviving to the extinction of the wild ox and to the eradication of its virus.

Of all cattle diseases, rinderpest was the most feared by farmers. The mortality could be very high in a herd, in a region, in a country. If today the disease is mostly forgotten in Europe, rinderpest had an influence on the organisation of agricultural landscapes during the past centuries. Epizootic waves used to arrive quite regularly from Central Europe steppes moving to the West of the continent [8]. The last outbreak, which happened at the beginning of the $\mathrm{XX}^{\text {th }}$ century, is at the origin of the foundation of the OIE in Paris in 1924.

The virus reservoir was probably in Asian cattle. America staid free of the disease but at the end of the XIX ${ }^{\text {th }}$ century an Italian army introduced the virus in Africa along the shores of Abyssinia. Infected Indian cattle landed in Massawa harbour, which is today in Eritrea, probably in 1887. The consequences have been catastrophic. Within a few years, the whole continent was concerned. Besides domestic cattle herds, wildlife, i.e. mainly wild ruminants and wild suidae, all completely naive in face of this virus, were all wiped out. Consequences for human beings were also very heavy when all they had was their livestock. 
Campaigns against rinderpest, as soon as a vaccine has been available, i.e. in the middle of the $\mathrm{XX}^{\text {th }}$ century, were a great success story of the veterinary profession and of the veterinary services. During all the 1990s and during the first years of the XXI ${ }^{\text {st }}$ century, the programme called PACE (Pan African Programme for the Control of Rinderpest and Epizootics) was able to look for the last outbreaks, the last endemic areas and to monitor and control the absence of virus in wildlife reservoir [1]. Hundreds of antelopes and of buffaloes were screened during all these years over the continent. The launching of a thermostable vaccine was a real technological progress [5]. Before that time it was difficult to guarantee a true chain of cold from the laboratory to the grazing pastures of nomadic herds.

In Asia the last outbreaks were also recorded at the very beginning of the $\mathrm{XXI}^{\text {st }}$ century and were detected in Mongolia, Russia and Pakistan. A few papers and reviews were published in famous international scientific periodics before the official notification of rinderpest eradication $[4,7]$. In some reports it was written that vaccinating cattle herds against rinderpest proved to be easier, even during war time in some parts of the world, than vaccinating children against childhood diseases [7]. This is certainly difficult to interpret properly but, for instance, poliomyelitis eradication was announced a few times already when today reality is still different. It is also possible to add that vaccination campaigns against rinderpest did not face such troubles as those leading to the murder of health workers in charge of vaccinating children in some unrest parts of the world.

Two years after rinderpest eradication, the same periodics mention that the virus is still the subject of research in some laboratories [2]. This has to be done under very specific biosecurity constraints. One of the topics is linked to try to provide a vaccine against peste-des-petits-ruminants virus which could also be able to protect against rinderpest. These two viruses are very close one from each other but the former is much milder. Such a vaccine could justify to keep in laboratories only peste-des-petits-ruminants virus and to stop manipulating the other one.

In terms of management, it can be mentioned that fighting against rinderpest helped starting to organise what will become the official services in charge of animal health within European countries [8] even if the coming of the veterinary services in the early $\mathrm{XX}^{\text {th }}$ century is rather linked to the campaigns against foot-and-mouth disease, another viral disease with a very high transmissibility but a much lower mortality than rinderpest [3].

Any comparison between diseases, between times, between countries has to be performed with great care. However rinderpest eradication represents a story, a process and a result of its own, really interesting. Besides its medical and technological aspects, rinderpest is also of interest for historians and sociologists.

\section{References}

1. Blancou J. (2000) Histoire de la surveillance et du contrôle des maladies animales transmissibles. OIE, Paris, $366 \mathrm{p}$.

2. Butler D. (2013) Rinderpest research restarts. Nature 499(7458): 264-5

3. Conseil général vétérinaire (2006) Histoire des services vétérinaires français. Association amicale du Conseil général vétérinaire, Paris, $477 \mathrm{p}$.

4. Gilbert N. (2009) Cattle disease faces total wipeout. Nature 462(7274):709

5. Mariner JC, House JA, Mebus CA, et al (2012) Rinderpest eradication: appropriate technology and social innovations. Science 337(6100):1309-12

6. Njeumi F, Taylor W, Diallo A, et al (2012) The long journey: a brief review of the eradication of rinderpest. Rev Sci Tech 31(3): $729-4$

7. Normile D. (2008) Rinderpest. Driven to extinction. Science 319(5870):1606-9

8. Vallat F (2009) Les bœufs malades de la peste. La peste bovine en France et en Europe. XVIII ${ }^{\mathrm{e}}$-XIX ${ }^{\mathrm{e}}$ siècle. Presses Universitaires de Rennes, Rennes, 360 p. 